\title{
Effect of thyme essential oil (Thymus vulgaris) on the growth of Salmonella Enteriditis and Salmonella paratyphi on surfaces of chilled raw bovine meat
}

\section{Karen Piedad Martinez}

University of Santander, Faculty of Health Sciences, CRISALIDA Research Group, Avenida 4 calle 10N-61, Cúcuta, Colombia. Postal code 540001

\section{Enrique Alfonso Cabeza}

University of Pamplona, Head of the Microbiology and Biotechnology research group GIMBIO, Cl. 5 \#3-

93, Pamplona, Colombia, Postal code 543050

Javier Andres Soto ( $\sim$ jav.soto@mail.udes.edu.co)

Universidad de Santander https://orcid.org/0000-0002-4786-3431

\section{Research}

Keywords: essential oils, meat, innocuousness, Salmonella, thyme

Posted Date: April 15th, 2020

DOI: https://doi.org/10.21203/rs.3.rs-18772/v1

License: (c) (i) This work is licensed under a Creative Commons Attribution 4.0 International License. Read Full License 


\section{Abstract}

Essential oils (EOs) are mostly composed of terpenes and phenolic compounds that are stored in secretory tissues of aromatic plants. This study evaluated the effect of both commercial and experimental thyme oil (cEO and eEO, respectively) on ATCC strains of Salmonella enteritidis and Salmonella paratyphi present on surfaces of chilled raw beef. The composition of each EO was analyzed chemically by gas chromatography coupled with spectrometry (GC-MS). The antimicrobial activity was assessed through the agar diffusion method and the minimum inhibitory concentration by means of the macro dilution method in broth, thus proving that a higher concentration of both cEO and eEO is required to reduce the growth of $S$. enteritidis compared to $S$. paratyphi. Similar results were obtained when pieces of beef previously inoculated with $10^{4} \mathrm{cfu} / \mathrm{ml}$ and kept at $0^{\circ} \mathrm{C}, 4^{\circ} \mathrm{C}$ and $10^{\circ} \mathrm{C}$ for 72 hours were treated with three concentrations of cEO and eEO. The in vivo approach showed that $S$. paratyphi is more sensitive to the action of EO than $S$. enteritidis and such sensitivity decreases when temperature increases. Overall, the cEO proved to be more effective than the eEO on the growth inhibition of the two species, showing in all cases a reduction greater than $10 \%$ for $S$. paratyphi at the concentration of $50 \%(v$ / v) and greater than $7 \%$ at the concentrations of 40 and 30\% (v / v), exhibiting a significant variation at a p-value $<0.05$. Regarding $S$. enteritidis, the values of reduction were $4.5 \%$ at $0^{\circ} \mathrm{C}$ and $4{ }^{\circ} \mathrm{C}$ and $3.5 \%$ at $10^{\circ} \mathrm{C}$ for the cEO, and higher than $1 \%$ for the eEO. It is concluded that the application of thyme EO on surfaces of meat contributes to reduce the presence of Salmonella spp. on this type of foodstuff.

\section{Introduction}

Meat is one of the final products of the bovine agroindustry and, due to the lability of its components, is considered as a food with a high public health risk (de Bogota 2013), because of several factors that have a direct relation with the predominant decomposing biota present in meat, including the availability of nutrients, oxygen, temperature and time of storage, $\mathrm{pH}$ and rate of proliferation of microorganisms (Ray et al. 2010). Meat provides a variety of nutrients, including proteins of high biological value which are necessary for bones, teeth and muscles genesis, and also promotes an increase in the rate of hemoglobin, characteristics that make this food one of high nutritional level (Huerta-Sanabria et al. 2018). Despite these positive properties, meat can also carry biological threats depending on the concentration of microorganisms and consumer resistance, among other factors (Delgado et al. 2015), and therefore their consumption is subject to increasingly rigorous surveillance, since this type of product can be contaminated at any stage of processing, from farm production to transport and preservation (No 2008). Due to its high-water activity value (aw), meat is susceptible to contamination with several microorganisms which use its substrates as a source of energy. The most frequent are Escherichia coli, Listeria monocytogenes, Clostridium spp, Staphylococcus aureus Campylobacter spp y Salmonella spp. (Ray et al. 2010) where Salmonella spp is a known enteropathogen transmitted to humans through contaminated food or water, and therefore the affectation related to these microorganisms is classified as a foodborne disease (Rodríguez et al. 2017). Humans are particularly vulnerable to $S$. typhi and $S$. paratyphi due to the ability of these strains to invade and multiply within host tissues. The invasion by 
this microorganism is related to gastrointestinal and septicemic problems and abortions, due to its great capacity of cellular invasion and intraphagocytic survival (Talero García 2019)

The livestock sector faces many challenges and its sustainability depends on productivity and competitiveness, as global consumers have led large, medium and small producers to offer higher quality food with an even longer shelf life (Cáffaro-Tommasiello et al. 2018; Figueroa Delgado 2019) resulting in the use of chemicals in meat industry for this purpose. However, after years of using these products, there is a clear risk related to health hazard for consumers, which has led to looking back to nature for bioprotective compounds.

Several countries exhibit a great diversity of ecosystems and microclimates which favor the presence of a very rich flora. Some of these endemic plants have essential oils with active principles that have proven to have biological or industrial applicability, with wide perspectives to carry out research and development of new products, including as antimicrobial agents (Correa-Pacheco et al. 2019). For instance, the essential oil obtained from thyme, Thymus vulgaris, contains thymol as the main component, and in some varieties its composition can yield values of up to $80 \%$. This phytochemical is recognized for its antibacterial and antifungal activity, thus this plant is used industrially in the preparation of human disinfectants, mouthwashes and other antimicrobial agents used at home (Alzate et al. 2009; RuedaPuente et al. 2018)In order to contribute to the implementation of effective and natural strategies to address the above challenges, the use of essential oils (EO) has assumed an important role, as the mixture of terpene components exhibits activity against common bacteria (Barrera et al. 2013) through mechanisms such as damage to membrane structure and function, inhibition of biosynthesis and function of nucleic acids, interference with essential metabolic processes, and disruption of normal cellular communication, among others (Gallegos-Flores et al. 2019; Radulovic et al. 2013). Based on the above context the objective of this study was to evaluate the effect of the essential oil obtained from thyme (Thymus vulgaris) on the growth of Salmonella enteritidis and Salmonella paratyphi present on surfaces of chilled raw beef.

\section{Materials And Methods}

\subsection{Obtaining Essential Oils (EO) from thyme.}

Two sources of thyme essential oil were used: a commercial oil produced by the NOW Foods industry (Bloomingdale, IL, USA) and another experimental oil extracted from thyme plants purchased in the local market.

-Commercial oil. According to the manufacturer's website (https://www.nowfoods.com/essentialoils/white-thyme-oil), this product is $100 \%$ pure essential oil derived from flowers of two varieties of white thyme: the common thyme (Thymus vulgaris) and the "salsero" thyme (Thymus zygis), obtained through a steam distillation method. 
-Experimental oil: The second type of essential oil was obtained from leaves and stems of vulgar thyme acquired at the local market, which was extracted by steam distillation method using a pilot plant with a capacity of $25 \mathrm{~kg}$ (University of Pamplona, Villa del Rosario).

\subsection{Determination of the Chemical Composition of Essential Oils.}

-Gas Chromatography - Mass Spectrophotometry of thyme essential oil: A determination of the volatile composition of the two types of oils was carried out through gas chromatography with a selective mass detector (GC-MS), according to the CM-PTSE-04 procedure, version 01, 2014-04-04; based on the ISO 7609,1985 (E) (ISO 1985). The chromatographic analysis was performed on an AT 6890 Series Plus gas chromatograph (Agilent Technologies, Palo Alto, California, USA), coupled to a selective mass detector (Agilent Technologies, MSD 5975) operated in full scan mode. The columns used in the analysis were DB5MS ( $\mathrm{J}$ and W Scientific, Folsom, CA, USA) (5\%-phenyl_poli (dimethylsiloxane), $60 \mathrm{~m} \times 0.25 \mathrm{~mm} \times 0.25$ $\mu \mathrm{m})$. Injection was performed in Split mode (30:1), Viny $=2 \mu \mathrm{l}$.

\subsection{EOs treatment approach.}

Different treatments applied both in vitro as in vivo to determine the antibacterial activity of both EOs are represented in Table 1. 
Table 1

Experimental design for the determination of the antimicrobial activity of thyme EA on $S$. enteritidis and S. paratyphi. EOs concentration expressed in percentage $(\mathrm{v} / \mathrm{v})$ and in $\mathrm{mg}^{\star} \mathrm{ml}^{-1}$. Ethanol was used as a solubilizing agent.

\begin{tabular}{|c|c|c|c|c|c|}
\hline \multirow[t]{2}{*}{ Essential Oil (EO) } & \multirow[t]{2}{*}{ EO Volumen (ml) } & \multirow[t]{2}{*}{ Ethanol Volumen (ml) } & \multicolumn{2}{|c|}{ EO concentration } & \multirow[t]{2}{*}{ Treatment } \\
\hline & & & $\%(v / v)$ & $(\mathrm{mg} / \mathrm{ml})$ & \\
\hline \multirow[t]{5}{*}{ Commercial } & 1 & 9 & 10 & 92,50 & $\mathrm{~T} 1$ \\
\hline & 2 & 8 & 20 & 185,00 & $\mathrm{~T} 2$ \\
\hline & 3 & 7 & 30 & 277,50 & T3 \\
\hline & 4 & 6 & 40 & 370,00 & $\mathrm{~T} 4$ \\
\hline & 5 & 5 & 50 & 462,50 & T5 \\
\hline \multirow[t]{5}{*}{ Experimental } & 1 & 9 & 10 & 92,62 & T6 \\
\hline & 2 & 8 & 20 & 185,24 & T7 \\
\hline & 3 & 7 & 30 & 277,86 & T8 \\
\hline & 4 & 6 & 40 & 370,48 & T9 \\
\hline & 5 & 5 & 50 & 463,10 & T10 \\
\hline
\end{tabular}

Prior to the evaluation of the microbial activity, thyme underwent Salmonella evaluation according to method NTC (Norma Tecnica Colombiana) 4574 following the horizontal method (4574 2007) for which a phase of pre-enrichment in a non-selective medium was performed, and along with a phase of selective enrichment, with the purpose of increasing the population of interest and inhibiting other microorganisms present. For this purpose, Rappaport broth was used, taking $1 \mathrm{ml}$ of the pre-enrichment culture and sowing it in a tube containing $10 \mathrm{ml}$ of broth, which was incubated at $42^{\circ} \mathrm{C}$ for 24 hours. Afterwards, a differential isolation was performed by taking an inoculum and seeding it in Lysine Xylose Deoxycholate (XLD), on Hektoen agar (Merck). The presence of Salmonella was not found in these tests after an incubation at $37^{\circ} \mathrm{C}$ for 24 hours.

- Salmonella enteritidis ATCC 17036 and Salmonella paratiphy ATCC 9150 strains obtained from University of Pamplona, Colombia. The strains were cultivated in nutritive broth and soy tripticase broth at $37^{\circ} \mathrm{C}$ for 24 hours before use.

- Inoculum standardization: An inoculum was taken from the strains and seeded in a tube containing 0.5 and $99.5 \mathrm{ml}$ of $0.18 \mathrm{M}$ barium chloride and $0.048 \mathrm{M}$ sulfuric acid, respectively. Such inoculum was 
incubated at $37^{\circ} \mathrm{C}$ for 2 to 4 hours and adjusted to 0.5 on the MacFarland scale to obtain $1.5 \times 10^{8}$ cells/ml.

- Determination of antibacterial activity by disk diffusion method: Antibacterial activity assessment was carried out according to Costa et al. (2013) with some modifications. Petri agar plates of Mueller-Hinton (BBL Becton Dickinson and Company) were inoculated by means of massive sowing with $0.1 \mathrm{ml}$ of $10^{6}$ ufc/ml of the standardized inoculum with Salmonella enteritidis and Salmonella paratiphy, each inoculum was allowed to dry for 5 minutes. Subsequently, sterile filter paper discs of $9 \mathrm{~mm}$ in diameter were permeated with 30 microliters of each essential oil at concentrations of $10 \%, 20 \%, 30 \%, 40 \%$ and $50 \%$ and then placed on the surface of the Mueller Hinton culture previously inoculated with each Salmonella strain. Plates were left for 15 minutes at $4^{\circ} \mathrm{C}$ to allow the pre-diffusion of the essential oils before incubation (Ramirez and Castaño 2009). Plates were then incubated at $37 \pm 0.5^{\circ} \mathrm{C}$ for 18 hours, as described by López (López-Oviedo et al. 2006). The standard method recommends that all final readings be taken at 18 hours, as it has been established that this is the point in which the interaction between microorganisms and the inhibitory effect of antibiotics is optimal. Ending the incubation, the inhibition halos were measured and the results were interpreted based on Celikel and Kavas (2008), -see Table 2a-. The assays were carried out in triplicates and discs permeated with absolute ethanol were used as negative control.

-Determination of Minimum Inhibitory Concentration (MIC) and Minimum Bactericidal Concentration $(M B C)$. MIC was identified through macro-dilution in broth method. Briefly, $0.1 \mathrm{ml}$ of standardized inoculum was added to tubes containing $9.8 \mathrm{ml}$ of sterile nutritive broth plus $0.1 \mathrm{ml}$ of commercial (cEO) and experimental (eEO) essential oil of thyme according to the concentrations identified in the agar diffusion assay described in table 1 . Tubes were incubated at $37^{\circ} \mathrm{C}$ for 18 hours. As control, one of the tubes did not contain EO. The experiments were developed in triplicates. After the identification of the MIC, a volume of $0.1 \mathrm{ml}$ was taken from the tubes that did not show increased in turbidity and sowed in nutritive agar to corroborate the inhibition of growth, allowing to determine the MBC. The first tube in the series that when seeded did not exhibit colony development represented the MBC of the antimicrobial compounds under study.

\subsection{Effects of EO and refrigeration temperature on the growth of Salmonella in fresh meat.}

- Meat preparation. First quality beef was cut into $1 \mathrm{~cm}^{2}$ pieces that were previously disinfected with 540 ppm Citrosan (Brand and city) for 2 mins. Later, the pieces were washed with sterile distilled water and the presence of Salmonella was evaluated in a fraction of 25 grams by the method described on the NTC 4574 (4574 2007). In addition, mesophilic aerobes, molds and yeasts were analyzed to rule out microbial contamination. 
Ten grams of meat were taken and placed in a bottle with $90 \mathrm{ml}$ of buffered water. Dilutions were made up to $10^{-3}$, and those of $10^{-2}$ and $10^{-3}$ were inoculated by pour plating seeded in deep plate using in plate counting agar and Saboraud agar. The remaining cuts were wrapped in sterile plastic wrapping foil and frozen until the results of Salmonella spp. were obtained.

-Microorganisms and development conditions. Salmonella enteritidis and Salmonella paratyphi strains were kept in Soy Tripticase Broth (STB) (Acumedia, UK) at $4^{\circ} \mathrm{C}$. The inoculum was obtained by cell culture in nutritive broth for 24 hours at $37^{\circ} \mathrm{C}$. The cell suspension was diluted with peptone water (Acumedia, UK) to provide an initial cell count close to $1.5 \times 10^{8} \mathrm{ufc} / \mathrm{ml}$ (McFarland 0.5). 24 hours prior to each experiment $0.1 \mathrm{ml}$ of culture was transferred to $9.9 \mathrm{ml}$ of nutrient broth.

-Inoculation of Salmonella spp. in beef. We applied a modified procedure to inoculate the meat (Dussault et al. 2014). After an initial period of incubation for 24 hours in STB, bacteria were resuspended in fresh medium and incubated for another 24 hours prior to the experiment, seeking to achieve working cultures of approximately $10^{9} \mathrm{cfu} / \mathrm{ml}$. On the day of meat inoculation, each culture was diluted $10^{4}$ times in peptone water in order to prepare a $10^{4}$ to $10^{5} \mathrm{cfu} / \mathrm{ml}$ inoculum solution and thus obtain a final concentration of $10^{3}$ to $10^{4} \mathrm{cfu} / \mathrm{g}$ in the meat pieces.

-Effect of essential oils. Once the meat was inoculated, each piece was individually sprayed with five different concentrations of $\mathrm{CEO}$ and eEO as described in table 1, plus controls. They were arranged in sterile plastic boxes and incubated at three temperatures: $0^{\circ} \mathrm{C}, 4^{\circ} \mathrm{C}$ and $10^{\circ} \mathrm{C}$, for 24,48 and 72 hours. In addition, controls used consisted of pieces of meat sprayed with ethanol, essential oils, and positive controls were pieces of meat with the bacteria without any treatment. The whole experiment was carried out in triplicate with three biological repetitions.

-Microbiological analysis. After incubation at different temperatures $\left(0,4\right.$ and $\left.10^{\circ} \mathrm{C}\right)$, a piece of meat was placed in peptone water $(9 \mathrm{ml})$, the microbial population diluted and then inoculated by pour plating in Tripticase Soy Agar (TSA) medium. Subsequently, the number of colonies present in the agar was counted and compared with the initial colony count to determine the percentage reduction at each time interval in each treatment used.

\subsection{Data analysis}

The effect of the essential oils was assessed by determining the growth/death rate for 72 hours, using a non-linear regression analysis with DMFit software, as well as determining the percentage reduction by comparing the final microbial load to the initial one.

-Statistical Analysis. For the statistical process an experimental design was applied in a Randomized Complete Block Design (RCBD) with three replicas for each treatment studied, thus covering all the possible combinations for each factor. The statistical evaluation was carried out by means of ANOVA/MANOVA variance analysis, and the Tukey-HSD multiple range test was used to compare means 
and identified statistically significant differences $(p<0.05)$ applying the Statgraphics Centurion XV.II software. In the case of outliers, a Kruskal-Wallis Test was used.

Final reduction percentages of Salmonella enteritidis and paratyphi were determined by comparing the mean of the counts for each time interval $(24 \mathrm{~h}, 48 \mathrm{~h}$ and $72 \mathrm{~h})$ versus the initial count $(0 \mathrm{~h})$. With these data, the mean speed of death was determined by means of non-linear regression analysis for each treatment using DMFit software.

\section{Results And Discussion}

\subsection{Physicochemical Characterization of Thyme Essential Oils.}

Table $2 b$ shows some biological features of both EOs. The physical composition of cEO and eOE was similar in terms of density, refractive index, odor and color. As for the percentage of yield obtained, it could only be determined for the eEO, exhibiting $0.15 \%$, value that falls within the nominal range of essential oils content for herbs and spices. In this regard, Tajkarimi report that herbs and spices contain essential oils (EOs) in a range of $0.05-0.1 \%$ (Tajkarimi et al. 2010). Table 3 represents the data obtained by gas chromatography with selective mass detector (GC-MS), showing the chemical composition of the evaluated oils, indicating the expressed retention time (minutes), the tentatively identified component and the relative quantity (\% abundance).

a)

\begin{tabular}{|ll|}
\hline DIAMETER & INTERPRETATION \\
\hline Less than $8 \mathrm{~mm}$ & Not sensitive \\
\hline Between 9 and 14 & Sensitive + \\
\hline Between 15 and $19 \mathrm{~mm}$ & very sensitive ++ \\
\hline Greater than $20 \mathrm{~mm}$ & Extremely sensitive +++ \\
\hline (Celikel and Kavas 2008) & \\
\hline
\end{tabular}

b) 
Table 2

a) Classification of the individual sensitivity to essential oils by the diameter of the inhibition zones

b) Physical and organoleptic characteristics of each thyme EO. ${ }^{1}$ The yield is based on a mixture of fresh and dry leaves and stems. N.D: not determined.

\section{Commercial Essential Oil (cEO)}

\begin{tabular}{|ll|}
\hline Feature & Value \\
\hline Relative density $(\mathrm{mg} / \mathrm{ml})$ & $925,0 \pm 0,14$ \\
\hline Refractive index $\left(25^{\circ} \mathrm{C}\right)$ & $1,497 \pm 0,007$ \\
\hline Percentage of extraction yield $(\%)$ & N.D. \\
\hline Odour & Characteristic \\
\hline Color & Light yellow \\
\hline
\end{tabular}

From this evaluation, 19 components were found in cEO, all of which were identified (100\%), while 33 components were found in the eEO, of which 32 were identified (97\%). The relative abundance of the cEO was represented by two major components (80\%): thymol (45.3\%) and p-cymene (30.3\%), and a smaller proportion by $\gamma$-terpinene ( $8.4 \%)$. Regarding the eEO, its relative composition varied substantially as the $p$ cymene is presented as the major component (43.8\%), following by trans- $\beta$-caryophyllene (6.2\%), thymol $(5.7 \%)$, a-pinene and limonene (4.2\% each). The compositions described are similar to other essential oils obtained from the same plant species with variation in their abundance percentages. It is worth mentioning that in the eOE the quantities of thymol were low and the presence of carvacrol was not found, unlike what was seen in the cEO. In this sense, some authors have found a relationship between thymol production and the presence or absence of carvacrol (D'Auria et al. 2005), which seems to be in accordance with the observations made in this study. However, the results obtained are similar to those found in another study, in which four main components were identified in hydroponically grown thyme essential oil in two nutrient solutions and three planting densities (Guerrero-Lagunes et al. 2011). These were thymol, $p$-cymene, $\mathrm{\gamma}$-terpinene and carvacrol, which presented an average abundance of $23.3 \%, 7.4 \%$, $4.9 \%$ and $1.1 \%$, respectively. These are comparable to those found by Omidbaigi and Arjmandi, who identified thymol as the major component of the essential oil on this species (Omidbaigi and Arjmandi 2001). However, the composition of thymol can range from $10-64 \%$ according to Lens (Lens-Lisbonne et al. 1987).

The lower composition variability identified in the cEO may be indicative of higher purity, as referred to by the supplier both on the commercial label and on the manufacturer's website (https://www.nowfoods.com/essential-oils/white-thyme-oil) (100\% purity). It should also be borne in mind that this is an essential oil obtained from two varieties of white thyme in its floral state, the 
common thyme (Thymus vulgaris) and the "salsero" thyme (Thymus zygis), by means of a steam distillation method under standardized conditions on an industrial scale; whereas the eEO was obtained from dried and fresh leaves and stems of vulgar thyme acquired in a local market, not knowing the phenological state of the plant or growing conditions, which may provide a lower purity, less abundance of active components and greater variety of components, as reflected on the table above. 
Table 3

Presumptive identification and relative quantity (\% abundance) of the components present in the samples of commercial and experimental thyme essential oil. Rt: resolution time.

\begin{tabular}{|c|c|c|c|c|c|c|c|}
\hline \multirow[t]{2}{*}{ Peak } & \multicolumn{3}{|c|}{ Commercial Essential Oil (cEO) } & \multirow[t]{2}{*}{ Peak } & \multicolumn{3}{|c|}{ Experimental Essential Oil (eEO) } \\
\hline & $\begin{array}{l}\text { Rt } \\
\text { (Min) }\end{array}$ & Compound & $\begin{array}{l}\text { Relative } \\
\text { abundance (\%) }\end{array}$ & & $\begin{array}{l}\text { Rt } \\
\text { (Min) }\end{array}$ & Compound & $\begin{array}{l}\text { Relative } \\
\text { abundance } \\
(\%)\end{array}$ \\
\hline 1 & 16,88 & a-Tujene & 0,1 & 1 & 16,88 & a-Tujene & 1,1 \\
\hline \multirow[t]{3}{*}{2} & 17,25 & a-Pinene & 1,2 & 2 & 17,25 & a-Pinene & 4,2 \\
\hline & & & & 3 & 18,02 & Canphene & 1,3 \\
\hline & & & & 4 & 18,99 & Sabinene & 0,2 \\
\hline 3 & 19,25 & $\beta$-Pinene & 0,3 & 5 & 19,25 & $\beta$-Pinene & 0,7 \\
\hline \multirow[t]{2}{*}{4} & 19,62 & $\beta$-Myrcene & 0,1 & & & & \\
\hline & & & & 6 & 20,45 & $\begin{array}{l}\text { a- } \\
\text { Phellandrene }\end{array}$ & 0,3 \\
\hline 5 & 20,56 & s-3-Carene & 0,1 & & & & \\
\hline 6 & 20,91 & a-Terpinene & 0,3 & 7 & 20,91 & a-Terpinene & 1,7 \\
\hline 7 & 21,32 & $p$-Cymene & 30,3 & 8 & 21,26 & $p$-Cymene & 43,8 \\
\hline 8 & 21,46 & Limonene & 0,6 & 9 & 21,54 & Limonene & 4,2 \\
\hline 9 & 21,56 & $\begin{array}{l}\text { a- } \\
\text { Phellandrene }\end{array}$ & 0,2 & 10 & 21,61 & $\begin{array}{l}\mathrm{a}- \\
\text { Phellandrene }\end{array}$ & 1,3 \\
\hline 10 & 21,62 & 1,8-Cineol & 0,4 & 11 & 21,66 & 1,8-Cineol & 2,1 \\
\hline \multirow[t]{3}{*}{11} & 22,69 & $\mathrm{Y}$-Terpinene & 8,4 & 12 & 22,65 & $\mathrm{Y}$-Terpinene & 1,9 \\
\hline & & & & 13 & 23,79 & Terpinolene & 0,6 \\
\hline & & & & 14 & 23,98 & $p$-Cymene & 0,2 \\
\hline 12 & 24,35 & Linalool & 4,1 & 15 & 24,32 & Linalool & 2,7 \\
\hline 13 & 27,40 & Borneol & 0,4 & 16 & 27,39 & Borneol & 0,1 \\
\hline 14 & 27,65 & Terpinen-4-ol & 0,5 & 17 & 27,65 & Terpinen-4-ol & 1,4 \\
\hline 15 & 28,20 & a-Terpineol & 1,6 & 18 & 28,18 & a-Terpineol & 0,5 \\
\hline 16 & 31,75 & Thymol & 45,3 & 19 & 31,63 & Thymol & 5,7 \\
\hline 17 & 32,00 & Carvacrol & 2,1 & & & & \\
\hline
\end{tabular}




\begin{tabular}{|c|c|c|c|c|c|c|c|}
\hline \multirow[t]{2}{*}{ Peak } & \multicolumn{3}{|c|}{ Commercial Essential Oil (cEO) } & \multirow[t]{2}{*}{ Peak } & \multicolumn{3}{|c|}{ Experimental Essential Oil (eEO) } \\
\hline & $\begin{array}{l}\text { Rt } \\
\text { (Min) }\end{array}$ & Compound & $\begin{array}{l}\text { Relative } \\
\text { abundance (\%) }\end{array}$ & & $\begin{array}{l}\text { Rt } \\
\text { (Min) }\end{array}$ & Compound & $\begin{array}{l}\text { Relative } \\
\text { abundance } \\
(\%)\end{array}$ \\
\hline \multirow[t]{2}{*}{18} & 36,76 & $\begin{array}{l}\text { Trans- } \beta- \\
\text { Caryophyllene }\end{array}$ & 3,3 & 20 & 39,76 & $\begin{array}{l}\text { Trans- } \beta \text { - } \\
\text { Caryophyllene }\end{array}$ & 6,2 \\
\hline & & & & 21 & 37,05 & $\beta$-Copaene & 1,2 \\
\hline \multirow[t]{12}{*}{19} & 37,97 & a-Humulene & 0,4 & 22 & 37,97 & a-Humulene & 0,5 \\
\hline & & & & 23 & 38,49 & y-Muurolene & 2,3 \\
\hline & & & & 24 & 38,57 & ar-Curcumene & 1,6 \\
\hline & & & & 25 & 39,07 & $\begin{array}{l}\mathrm{Nl} \text {, Compound } \\
\mathrm{M}+204\end{array}$ & 0,7 \\
\hline & & & & 26 & 39,74 & $Y$-Cadinene & 1,2 \\
\hline & & & & 27 & 39,83 & $s$-Cadinene & 3,3 \\
\hline & & & & 28 & 39,97 & Calamenene & 1,6 \\
\hline & & & & 29 & 40,61 & a-Calacoreno & 0,3 \\
\hline & & & & 30 & 41,745 & Espatulenol & 1 \\
\hline & & & & 31 & 41,94 & $\begin{array}{l}\text { Caryophyllene } \\
\text { oxide }\end{array}$ & 0,9 \\
\hline & & & & 32 & 45,97 & Xantorrizol & 0,5 \\
\hline & & & & 33 & 62,36 & $\begin{array}{l}\text { Diisooctyl } \\
\text { phthalate }\end{array}$ & 4,5 \\
\hline
\end{tabular}

Figure 1 shows the reconstructed total ionic current (chromatogram) of the volatile compounds of the cEO analyzed by GC-MS operated in full scan mode, in which two major components stand out: thymol (31.751 $\mathrm{min}$ ) and p-cymene (21.321 $\mathrm{min})$, and to a lesser extent, $\gamma$-terpinene, with a resolution time of $22,685 \mathrm{~min}$. Figure 2 shows the spectrum corresponding to $y$-terpinene obtained in the cEO sample, in which the molecular ion limit was 136 (figure 2a), and the peak base was 93 (figure 2b) for the same component, but obtained from the Wiley 275.L database; data indicative of the presence of this molecule. In this way, the compounds of each peak obtained from the chromatographic analysis from both EOs were identified, according to its mass spectrum and compared with the most similar spectrum of the reference database.

Although the biosynthesis and accumulation of thyme essential oil are genetically controlled, its chemical composition is also affected by a number of geographical, geobotanical and environmental factors such 
as temperature, light, climate, altitude, soil type and rainfall (Baranauskienè et al. 2003; Curioni et al. 2002; Figueiredo et al. 2008; Tajkarimi et al. 2010). Within the compendium of factors associated with differences in oil composition it has been proved that agronomic conditions such as fertilization, sowing density and cultivation method influence the quantity and quality of essential oil (Boskovic et al. 2015; Guerrero-Lagunes et al. 2011; Naghdi Badi et al. 2004). Other elements such as time and mode of collection, plant part, material handling and the obtaining process can affect composition (Albado Plaus et al. 2001; Bandoni et al. 2009), making it almost impossible to obtain two identical essential oils (Bandoni et al. 2009).

Other studies found similar results, since these works also evaluated the essential oil of thyme as well as oregano (Boskovic et al. 2015; Muñoz López de Bustamante 2002), finding thymol with an abundance of $50.48 \%$, followed by $p$-cymene with $24.79 \%$, linalool with $4.69 \%$, and y-terpinene with $4.14 \%$, concentrations very similar to our observations. The presence of $p$-cymene, $y$-terpinene, carvacrol and thymol in the two EO samples tested are an indicator that these four components are biologically and functionally related and supports the hypothesis that thymol is formed via p-cymene from y-terpinene in T. vulgaris (Burt 2004; Kokkini et al. 1997).s

In the cEO sample, thymol (2-isopropyl-5-methylphenol) was the major component with $45.3 \%$, whereas in the eEO it barely reached $5.7 \%$ (Table 2). One of the main characteristics and properties of thymol as a phenolic compound is its bactericidal, pesticidal and fungicidal potential. Thymol belongs to terpenes group of terpenes and can often be miscalled with the carvacol isomer, which can also be found in thyme essential oil and is structurally very similar to carvacrol, having the hydroxyl group in a different location of the phenolic ring (Lambert et al. 2001).

p-cymene (1-methyl-4-(1-methylethyl)benzene) found in the cEO represents the second constituent with a $30.3 \%$, while in the eEO it was the main component with $43.8 \%$ (Table 2). This naturally occurring aromatic organic compound is classified as an alkylbenzene monoterpene obtained from aromatic plants (thyme, cumin). The biological precursor of carvacrol, p-cymene, is hydrophobic and causes cytoplasmic membrane swelling more largely than carvacrol (Ultee et al. 2002). p-cymene is not an effective antibacterial molecule when used alone (Dorman and Deans 2000; Juliano et al. 2000; Juven et al. 1994; Ultee et al. 2000), but in combination with carvacrol it is has been reported to have synergism against bacteria such as Bacillus cereus in vitro and in rice samples (Ultee et al. 2002). It is hypothesized that such synergy occurs when $p$-cymene is incorporated into the lipid bilayer which most likely facilitates the transport of carvacrol across the cytoplasmic membrane (Ultee et al. 2002).

\subsection{Agar diffusion tests.}

Results obtained from agar diffusion tests for Salmonella enteritidis and Salmonella paratyphi are shown in Table 4. Data are presented based on the sensitivity taking into account the inhibition halos as follows: Extremely sensitive (+++) for diameters above $20 \mathrm{~mm}$, very sensitive (++) for diameters between 15 and $19 \mathrm{~mm}$, sensitive (+) for diameters between 9 and $14 \mathrm{~mm}$ and non-sensitive (-) for diameters below $8 \mathrm{~mm}$ (Ponce et al. 2003). 
According to the sensitivity obtained (Table 4), S. paratyphi showed to be more sensitive to thyme essential oil than S. enteritidis, as $50 \%$ of the treatments tested yielded inhibition halos with areas greater than $9 \mathrm{~mm}$, whereas for $S$. enteritidis just treatment five (T5) yielded a halo greater than $9 \mathrm{~mm}$. This could indicate that thyme essential oil can be considered as a possible natural additive for food preservation. The refractoriness of $S$. enteritidis does not represent a barrier to this potential application, it only endorses the claim that biological safety of food is based on one or more preservation methods. Cabeza (2015) stresses the importance of considering that in vitro studies are just an approximation of what could happen when an antimicrobial agent is subjected to a food matrix as a preservative, since intrinsic factors of a product such as fat content, proteins, salts, $\mathrm{pH}$ and extrinsic factors such as temperature can affect the bioactivity of compounds (Cabeza Herrera et al. 2015).

Table 4

Agar diffusion test results for each Salmonella species assessed. Columns without common letters indicate significant differences for a $p<0.05$ value.

S:D: standard deviation.

\begin{tabular}{|lllllll|}
\hline \multirow{2}{*}{ Treatment } & \multicolumn{5}{l}{ Diameter of inhibition halo (mm) } \\
\cline { 2 - 7 } & \multicolumn{2}{l}{ S. Paratyphi } & \multicolumn{4}{l|}{ S. Enteritidis } \\
\cline { 2 - 7 } & Media & S.D & Sensitivity & Media & S.D. & Sensitivity \\
\hline T1 & $4,33^{\mathrm{b}}$ & 0,577 & $(-)$ & $3,00^{\mathrm{bc}}$ & 1,000 & $(-)$ \\
\hline T2 & $6,33^{\mathrm{c}}$ & 0,577 & $(-)$ & $5,00^{\mathrm{d}}$ & 0,000 & $(-)$ \\
\hline T3 & $10,00^{\mathrm{e}}$ & 0,000 & $(+)$ & $8,00^{\mathrm{f}}$ & 0,000 & $(-)$ \\
\hline T4 & $12,00^{\mathrm{f}}$ & 0,000 & $(+)$ & $8,67^{\mathrm{f}}$ & 0,577 & $(-)$ \\
\hline T5 & $12,00^{\mathrm{f}}$ & 0,000 & $(+)$ & $9,67^{\mathrm{g}}$ & 0,577 & $(+)$ \\
\hline T6 & $2,33^{\mathrm{a}}$ & 0,577 & $(-)$ & $1,00^{\mathrm{a}}$ & 0,000 & $(-)$ \\
\hline T7 & $4,00^{\mathrm{b}}$ & 1,000 & $(-)$ & $2,00^{\mathrm{b}}$ & 0,000 & $(-)$ \\
\hline T8 & $7,67^{\mathrm{d}}$ & 0,577 & $(-)$ & $2,33^{\mathrm{b}}$ & 0,577 & $(-)$ \\
\hline T9 & $9,33^{\mathrm{e}}$ & 1,155 & $(+)$ & $3,33^{\mathrm{c}}$ & 0,577 & $(-)$ \\
\hline T10 & $10,33^{\mathrm{e}}$ & 0,577 & $(+)$ & $6,33^{\mathrm{e}}$ & 0,577 & $(-)$ \\
\hline
\end{tabular}

Data obtained from these tests regarding the type of essential oil clearly showed that the cEO exhibits stronger effects, an observation that could be explained by its chemical composition as it has higher amounts of thymol and p-cymene, which act as antimicrobials. On the other hand, this oil was obtained 
from two varieties of thyme plants in floral state since it has been reported that EOs obtained from herbs and spices collected during or immediately after the flowering process have stronger antimicrobial activity (Burt 2004). It has been observed that the Thymus zygis' EO exhibits greater antibacterial power than its counterpart of T. vulgaris when tested against Salmonella enteritidis and Escherichia coli 0157:H7 (Rota et al. 2008), hence the mixture of chemotypes in the cEO (T.zygis - T.vulgaris), as well as the higher presence of phenolic compounds, alcohols and thymol compared to the eEO suggests a synergistic action between such components and their relative amounts (Burt 2004).

\subsection{Minimum Inhibitory Concentration and Minimum Bactericidal Concentration.}

Based on the results obtained from the above tests, MIC of both essential oils on bacterial proliferation was determined (Table 5 and 6). Data obtained related to MIC of both EOs on $S$. enteritidis allowed inferring the absence of turbidity in culture broths in concentrations higher than $0.5 \%$, yielding a MIC of $5.55 \mathrm{mg} / \mathrm{ml}$ as indicated in the yellow column (Table 5). Likewise, in relation to eEO, absence of turbidity was found at higher concentrations compared to its commercial counterpart (0.7\%), so the MIC was placed at a concentration of $7.41 \mathrm{mg} / \mathrm{ml}$. Regarding Salmonella paratyphi test, MIC data of both EOs is depicted in Table 6. In this case, results obtained from the disc diffusion test were confirmed, as $S$. paratyphi inhibition halos were higher compared for those of $S$. enteritidis, indicating a higher sensitivity of the first species. MIC for both oils against S.paratyphi was lower than that observed for $S$. enteritidis at $4.625 \mathrm{mg} / \mathrm{ml}$ (cEO) and $5.557 \mathrm{mg} / \mathrm{ml}$ (eEO), respectively (Table 6).

Regarding the Minimum Bactericidal Concentration it can be inferred from the results obtained that the bactericidal effect of commercial thyme oil on S. enteritidis and S.paratyphi strains was evidenced at a concentration of $5.55 \mathrm{mg} / \mathrm{ml}$ and $4.625 \mathrm{mg} / \mathrm{ml}$, respectively, while the experimental thyme oil was able to kill the microorganisms at concentrations corresponding to $7.41 \mathrm{mg} / \mathrm{ml}$ and $5.55 \mathrm{mg} / \mathrm{ml}$, respectively, as depicted in Tables 7 and 8, respectively

These findings are similar to those reported by another study, where it was found that $S$. Enteritidis was more resistant than S. typhimurium to the action of thymol and carvacrol obtained from oregano's EO (Boskovic et al. 2015). Likewise, another approach also found comparable observations regarding the increased sensitivity of $S$. typhimurium compared to $S$. Enteritidis to the EOs of various thyme chemotypes (Rota et al. 2008).

The antimicrobial mechanism of carvacrol and thymol, which are the two main components of our EOs, is based on their ability to disintegrate the external membrane of Gram-negative bacteria due to loss of proton gradient and hence reduction in ATP synthesis (Tajkarimi et al. 2010). 
Table 5

Assays of evaluation of the Minimum Inhibitory Concentration required to inhibit the in vitro growing of Salmonella entiriditis.

\begin{tabular}{|c|c|c|c|c|c|c|c|c|c|}
\hline \multicolumn{10}{|c|}{ Salmonella enteritidis (MIC of cEO) } \\
\hline Tube & 1 & 2 & 3 & 4 & 5 & 6 & 7 & 8 & 9 \\
\hline$\%$ & 0.1 & 0.2 & 0.3 & 0.4 & 0.5 & 0.6 & 0.7 & 0.8 & 0.9 \\
\hline$(\mathrm{mg} / \mathrm{m}$ & 0.9 & 1.85 & 2.775 & 3.7 & 4.625 & 5.55 & 6.475 & 7.4 & 8.325 \\
\hline Turbidi & $y+$ & + & + & + & + & - & - & - & - \\
\hline \multicolumn{10}{|c|}{ Salmonella enteritidis (MIC of eEO) } \\
\hline Tube & 1 & 2 & 3 & 4 & 5 & 6 & 7 & 8 & 9 \\
\hline$\%$ & 0.1 & 0.2 & 0.3 & 0.4 & 0.5 & 0.6 & 0.7 & 0.8 & 0.9 \\
\hline (mg/ml) & 0.926 & 1.852 & 2.779 & 3.705 & 4.631 & 5.557 & 6.483 & 7.41 & 8.336 \\
\hline Turbidity & + & + & + & + & + & + & + & - & - \\
\hline
\end{tabular}

Table 6

Assays of evaluation of the Minimum Inhibitory Concentration required to inhibit the in vitro growing of Salmonella paratyphi.

\begin{tabular}{|c|c|c|c|c|c|c|c|c|c|}
\hline \multicolumn{10}{|c|}{ Salmonella paratyphi (MIC of cEO) } \\
\hline Tube & 1 & 2 & 3 & 4 & 5 & 6 & 7 & 8 & 9 \\
\hline$\%$ & 0.1 & 0.2 & 0.3 & 0.4 & 0.5 & 0.6 & 0.7 & 0.8 & 0.9 \\
\hline$(\mathrm{mg} / \mathrm{ml})$ & 0.92 & $5 \quad 1.85$ & 2.775 & 3.7 & 4.625 & 5.55 & 6.475 & 7.4 & 8.325 \\
\hline Turbidit & + & + & + & + & - & - & - & - & - \\
\hline \multicolumn{10}{|c|}{ Salmonella paratyphi (MIC of eEO) } \\
\hline Tube & 1 & 2 & 3 & 4 & 5 & 6 & 7 & 8 & 9 \\
\hline$\%$ & 0.1 & 0.2 & 0.3 & 0.4 & 0.5 & 0.6 & 0.7 & 0.8 & 0.9 \\
\hline$(\mathrm{mg} / \mathrm{ml})$ & 0.926 & 1.852 & 2.779 & 3.705 & 4.631 & 5.557 & 6.483 & 7.41 & 8.336 \\
\hline Turbidity & + & + & + & + & + & - & - & - & - \\
\hline
\end{tabular}


Table 7

Assays of evaluation of the Minimum Bactericidal Concentration required to inhibit the in vitro growing of Salmonella enteriditis

\begin{tabular}{|llllll|}
\hline \multicolumn{6}{|c|}{ Salmonella enteritidis (MBC of cEO) } \\
\hline Tube & 1 & 2 & 3 & 4 & 5 \\
\hline$\%$ & 0.6 & 0.7 & 0.8 & 0.9 & 1.0 \\
\hline$(\mathrm{mg} / \mathrm{ml})$ & 5.55 & 6.475 & 7.4 & 8.325 & 9.245 \\
\hline Turbidity & - & - & - & - & - \\
\hline \multicolumn{7}{|c}{ Salmonella enteritidis (MBC of eEO) } \\
\hline Tube & 1 & 2 & 3 & 4 & 5 \\
\hline$\%$ & 0.8 & 0.9 & 1.0 & 1.1 & 1.2 \\
\hline (mg/ml) & 7.41 & 8.336 & 9.25 & 10.17 & 11.09 \\
\hline Turbidity & - & - & & & \\
\hline
\end{tabular}

Table 8

Assays of evaluation of the Minimum Bactericidal Concentration required to inhibit the in vitro growing of Salmonella paratiphy.

\begin{tabular}{|lllllll|}
\hline \multicolumn{7}{c}{ Salmonella paratyphi (MBC of cEO) } \\
\hline Tube & 1 & 2 & 3 & 4 & 5 & 6 \\
\hline$\%$ & 0.5 & 0.6 & 0.7 & 0.8 & 0.9 & 1.0 \\
\hline (mg/ml) & 4.625 & 5.55 & 6.475 & 7.4 & 8.325 & 9.25 \\
\hline Turbidity & - & - & - & - & - & \\
\hline \multicolumn{7}{c}{ Salmonella paratyphi(MIC of eEO) } \\
\hline Tube & 1 & 2 & 3 & 4 & 5 & 6 \\
\hline$\%$ & 0.6 & 0.7 & 0.8 & 0.9 & 1.0 & 1.2 \\
\hline (mg/ml) & 5.557 & 6.483 & 7.41 & 8.336 & & \\
\hline Turbidity & - & - & - & - & - & - \\
\hline
\end{tabular}




\section{spp. in raw meat}

Figure 3 shows the outcome of the antimicrobial effect of both EOs on Salmonella paratyphi in portions of chilled meat at temperatures of $0^{\circ} \mathrm{C}, 4^{\circ} \mathrm{C}$ and $10^{\circ} \mathrm{C}$. In this case, six treatments were evaluated for each temperature, corresponding to the concentrations of $30 \%, 40 \%$ and $50 \%$ of both oils.

In all cases it was observed that T5 treatment ( $50 \%$ cEO), equivalent to a concentration of $462.5 \mathrm{mg} / \mathrm{ml}$, achieved the highest growth inhibition of $S$. paratyphi. This reduction was constant for 72 hours, reaching $12.68 \%, 11.45 \%$ and $10.88 \%$ at temperatures of $10{ }^{\circ} \mathrm{C}, 4^{\circ} \mathrm{C}$ and $0{ }^{\circ} \mathrm{C}$, respectively (Fig. 3 ). On the other hand, treatments T3 and T4 (equivalent to $30 \%$ and $40 \%$ of cEO) significantly reduced the growth of $S$. paratyphi at all temperatures during the first 24 hours, and then stabilize the population for the following 48 hours, achieving a diminution of observational units from approximately $7-8 \%$ in all cases (Fig. 3), without finding statistically significant differences between these treatments. From this analysis, it could be considered that CEO at a concentration of $50 \%$ behaves as a medium potency bactericidal agent when applied on a meat matrix, while at concentrations between $30 \%$ and $40 \%$ the bactericidal effect is maintained during the first 24 hours and then reduced to a bacteriostatic agent.

The effect of the eEO on the growth of $S$. paratyphi was lower in all cases compared to its counterpart. Only treatment $\mathrm{T} 10(50 \%)$ managed to reduce proliferation at temperatures of $0{ }^{\circ} \mathrm{C}$ and $4{ }^{\circ} \mathrm{C}$ to 72 hours in a range of $7-8 \%$, whereas $\mathrm{T} 8$ and $\mathrm{T} 9$ reduced growth by around $5.5 \%$ regardless of temperature. eEO can be considered as a medium to low-power bactericidal agent that maintains its bactericidal character for 72 hours (Fig. 3). The above results are congruent with the death rate values obtained for each treatment shown in Table 9.

Table 9

Death rate of $S$. paratyphi for the most efficient treatments evaluated on chilled beef slice.

\begin{tabular}{|clll|}
\hline \multirow{2}{*}{ Treatment } & \multicolumn{2}{c|}{ Maximum speed of death $\left(\mu_{\text {máx }}-\log _{10}\right.$ ufc/g*h $)$} \\
\cline { 2 - 4 } & $\mathbf{0}^{\circ} \mathrm{C}$ & $\mathbf{4}^{\circ} \mathrm{C}$ & $\mathbf{1 0}{ }^{\circ} \mathrm{C}$ \\
\hline T3 (cEO30\%) & $0,0119 \pm 0,0003$ & $0,0122 \pm 0,0012$ & $0,0126 \pm 0,0016$ \\
\hline T4 (cEO40\%) & $0,0123 \pm 0,0012$ & $0,0130 \pm 0,0013$ & $0,0131 \pm 0,0010$ \\
\hline T5 (cEO50\%) & $0,0127 \pm 0,0010$ & $0,0136 \pm 0,0019$ & $0,0145 \pm 0,0030$ \\
\hline T8 (eEO30\%) & $0,0049 \pm 0,0017$ & $0,0046 \pm 0,0017$ & $0,0047 \pm 0,0018$ \\
\hline T9 (eEO40\%) & $0,0042 \pm 0,0008$ & $0,0044 \pm 0,0022$ & $0,0048 \pm 0,0021$ \\
\hline T10 (eEO50\%) & $0,0053 \pm 0,0014$ & $0,0048 \pm 0,0010$ & $0,0041 \pm 0,0015$ \\
\hline
\end{tabular}


As for the rate of death of S. paratyphi, an opposite effect was observed between the two samples of EO, as cEO-induced death increases with increasing temperature, whereas in the eEO treatment this rate appears to decrease with increasing temperature, with the exception of treatment T9. These observations may respond to the chemical composition of each oil, where the main components can diffuse more easily through the cell membrane when the temperature increases or decreases. Although the properties of spice and herb essential oils and their components have long been studied, the mechanism of action of antimicrobial EO components is not known in detail (Burt 2004; Lambert et al. 2001). Given the large number of chemical components present in EOs, it is likely that the antibacterial activity is not consequence of a single mechanism, but they may rather act on several cellular targets (Carson et al. 2002; Skandamis et al. 2001). However, more specific studies evaluating the effect of temperature on the diffusion capacity are needed to clarify these assumptions.

On the other hand, the antimicrobial effect of both oils on $S$. Enteritidis revealed that the highest decrease in growth was reached with treatment T5 (50\% cEO), however, and unlike what was observed for $S$. Paratyphi, T3 and T4 treatments also reduced the population of $S$. Enteritidis to concentrations similar to $\mathrm{T} 5$ at all temperatures, without statistically significant differences (data not shown). The final reduction values were similar at temperatures of $0{ }^{\circ} \mathrm{C}$ and $4{ }^{\circ} \mathrm{C}$ (between $4 \%$ and $5 \%$ ), but higher than those observed at $10{ }^{\circ} \mathrm{C}(<3.5 \%)$ (data not shown). In all cases, the reduction of $S$. Enteritidis was evidenced during the first 24 hours, remaining stable for the next 48 hours. This suggests that treatment of $S$. Enteritidis with cEO appears to act as a bactericidal agent only in the first 24 hours of application and then reduced to a bacteriostatic agent.

All eEO treatments had minimal effect on $S$. Enteritidis, as the maximum reduction achieved (T10 at $10{ }^{\circ} \mathrm{C}$ ) does not exceed $2.3 \%$ compared to the initial inoculated population. In this case, it could be indicated that this EO has sparse or no effect on $S$. enteritidis when applied as a food preservative. The above results were reflected in the $S$. enteritidis mortality rate values obtained for each treatment, which are shown in Table 10. These data are comparable to those reached with this oil for S. paratyphi, since the highest death rate was achieved with the $\mathrm{T} 5$ treatment at $0{ }^{\circ} \mathrm{C}$, a value that was 1.6 times lower than the highest death rate observed in S. paratyphi under the same approach $\left(0.0092 \log 10 \mathrm{ufc} / \mathrm{g}^{*} \mathrm{~h}\right.$ vs $0.0145 \log 10$ ufc/g*h, respectively). 
Table 10

Death rate of $S$. Enteriditis for the most efficient treatments evaluated on chilled beef slice.

\begin{tabular}{|clll|}
\hline \multirow{2}{*}{ Treatment } & \multicolumn{3}{c|}{ Maximum speed of death $\left(\mu_{\text {máx }}-\log _{10}\right.$ ufc/g*h) } \\
\cline { 2 - 4 } & $\mathbf{0}{ }^{\circ} \mathrm{C}$ & $\mathbf{4}^{\circ} \mathrm{C}$ & $10^{\circ} \mathrm{C}$ \\
\hline T3 (cEO30\%) & $0,0070 \pm 0,0008$ & $0,0072 \pm 0,0007$ & $0,0040 \pm 0,0006$ \\
\hline T4 (cEO40\%) & $0,0078 \pm 0,0006$ & $0,0084 \pm 0,0004$ & $0,0044 \pm 0,0011$ \\
\hline T5 (cEO50\%) & $0,0092 \pm 0,0031$ & $0,0087 \pm 0,0005$ & $0,0054 \pm 0,0003$ \\
\hline T8 (eEO30\%) & $0,0002 \pm 0,0001$ & $0,0005 \pm 0,0003$ & $0,0006 \pm 0,0005$ \\
\hline T9 (eEO40\%) & $0,0016 \pm 0,0004$ & $0,0016 \pm 0,0004$ & $0,0002 \pm 0,0006$ \\
\hline T10 (eEO50\%) & $0,0019 \pm 0,0004$ & $0,0018 \pm 0,0002$ & $0,0018 \pm 0,0002$ \\
\hline
\end{tabular}

The bacteriostatic and bactericidal mechanisms related to the oils evaluated reflected in our approaches can be argued on the basis of various causes. It has been proposed that antibacterial properties of essential oils increase when these contain a high percentage of phenolic components (Boskovic et al. 2015). The aforementioned authors add that oil obtained from oregano exhibits a better antibacterial effect than thyme, an argument supported by Burt, who indicates that the effectiveness of spice OEs decreases in order of antimicrobial activity as follows: oregano > clove > cinnamon > cinnamon > coriander $>$ thyme $>$ mint $>$ rosemary $>$ mustard (Burt 2004).

According to the above, based on the results obtained from our in vitro and in vivo tests and in accordance to previous work (Tajkarimi et al. 2010), the two essential oils of thyme (commercial and experimental) can be used as agents that control or prevent the growth of pathogenic microorganisms, in particular Salmonella spp. rather than as preservatives (those that prevent or avoid processes of food alteration). The effectiveness of the essential oil of various spices, including thyme, depends on various factors such as $\mathrm{pH}$, storage temperature, amount of oxygen, oil concentration and active components and the EOs applied directly to foods is decreased compared to in vitro activity tests, due to the influence of various factors that have not been tested under the same conditions (Stoicov et al. 2009; Tajkarimi et al. 2010). In addition to the above factors, it should be noted a high fat content in meat products can reduce the action of essential oils (Burt 2004).

All the above data are clear evidence that $S$. enteritidis is more resistant to the effect of EO than $S$. paratyphi, and even with the low activity shown by the eEO, the application of these essential oils can prevent or at least control the growth of these food-borne pathogens.

\section{Conclusions}


As a result of the present research, the chemical composition of each essential oil was evaluated, finding 19 components in cEO and 39 in eEO, with thymol (45.3\%) and p-cimene (30.3\%) being the major components in cEO, and to a lesser extent y-terpineneh (8.4\%), while the eEO exhibited p-cimene (43.8\%) as the main molecule and in lower concentrations trans- $\beta$-caryophyllus $(6.2 \%)$ and thymol $(5.7 \%)$.

We were also able to determine that there is antibacterial activity by the two oils evaluated in the Salmonella enteritidis and Salmonella paratyphi strains, observing a greater sensitivity of the former to the action of the oils. It was also found that commercial oil was more effective compared to oil extracted on a laboratory scale, due in part to its higher purity, type and concentration of chemical components, the flowering state of the plant at the time of collection, and perhaps due to the extraction method used.

From this study, we were able to extract the evidence related to the greater antibacterial activity in vivo for commercial oil, which was obtained at a concentration of $465 \mathrm{mg} / \mathrm{ml}$, reducing the growth of Salmonella paratyphi by more than $10 \%$ and that of Salmonella enteritidis by $3.35 \%$.

It was also observed that thyme EO behaves in vitro as an antibacterial agent that decreases the presence of Salmonella enteritidis and Salmonella paratyphi, while in vivo testing in raw chilled meat shows it as a bactericidal-bacteriostatic agent, as it decreases the initial load of Salmonella spp. but does not inhibit its growth over time. Finally, it is noted that Salmonella enteritidis is more resistant to the effect of thyme essential oil than Salmonella paratyphi, but that even with the lower activity exhibited by eEO, the use of these essential oils could prevent or at least control the growth of these food-borne pathogens and thus increase the shelf life of foods, especially raw meats.

\section{Abbreviations}

EOs: Essential oils; GC-MS: Gas Chromatography coupled with Mass Spectrometry; NTC: Norma Tecnica Colombiana; XLD: Lysine Xylose Deoxycholate; MIC: Minimum Inhibitory Concentration; MBC: Minimum Bactericidal Concentration; STB: Soy Tripticase Broth; RCBD: Randomized Complete Block Design, TSA: Tripticase Soy Agar.

\section{Declarations}

\section{Consent for publication}

The authors approved the consent for publishing the manuscript.

\section{Competing interests}

The authors declare that they have no competing interests. The Editor may ask for further information relating to competing interests.

\section{Ethical statement and consent to participate}


This article does not contain studies by any of the authors on humans and animals. All associated authors are listed within the manuscript, and no other person satisfied the criteria for authorship.

\section{Funding}

NA

\section{Authors' contributions}

KM has contributed significantly to the development of all procedures related with in vitro assays. EC has intervened with the methodological development and the objectives of this work and has also contributed to the analysis of the results and the study of their implication. JS has contributed with the analysis of the results as well as in the redistribution of the sections of the manuscript and the screening of the most important information of the study to be published. The authors have given final approval of the version to be published. All authors read and approved the final manuscript.

\section{Acknowledgements}

NA.

\section{Availability of data and materials}

NA.

\section{References}

4574 NT (2007) Norma técnica colombiana microbiología (NTC4574) de alimentos y alimentos para animales. método horizontal para la detección de salmonella spp.

Albado Plaus E, Saez Flores G, Grabiel Ataucusi S (2001) Composición química y actividad antibacteriana del aceite esencial del Origanum vulgare (orégano). Revista Medica Herediana 12(1): 1619

Alzate DA, Afanador L, Durango DL, García CM (2009) Evaluación de la fitotoxicidad y la actividad antifúngica contra Colletotrichum acutatum de los aceites esenciales de tomillo (Thymus vulgaris), limoncillo (Cymbopogon citratus), y sus componentes mayoritarios. Vitae 16(1): 116-125

Bandoni AL, RETTA D, LIRA PMDL, van BAREN CM (2009) ¿ Son realmente útiles los aceites esenciales? Boletín Latinoamericano y del Caribe de Plantas Medicinales y Aromáticas 8(5): 317-322

Baranauskienė R, Venskutonis PR, Viškelis P, Dambrauskienė E (2003) Influence of nitrogen fertilizers on the yield and composition of thyme (Thymus vulgaris). Journal of Agricultural and Food chemistry 51(26): 7751-7758 
Barrera C, Andrés C, Acosta GE (2013) Antibacterial activity and chemical composition of essential oils of rosemary (Rosmarinus officinalis), thyme (Thymus vulgaris) and turmeric (Curcuma longa) from Colombia. Revista Cubana de Plantas Medicinales 18(2): 237-246

Boskovic M, Zdravkovic N, Ivanovic J, Janjic J, Djordjevic J, Starcevic M, Baltic MZ (2015) Antimicrobial activity of thyme (Tymus vulgaris) and oregano (Origanum vulgare) essential oils against some foodborne microorganisms. Procedia Food Science 5: 18-21

Burt S (2004) Essential oils: their antibacterial properties and potential applications in foods-a review. International journal of food microbiology 94(3): 223-253

Cabeza Herrera E, Herrera R, Ortega D (2015) Actividad inhibitoria de extractos de Plutarchia coronaria sobre Salmonella serotipo Enteritidis ATCC 17036 - Inhibotory activity of Plutarchia coronaria extracts on Salmonella serotype Enteritidis ATCC 17036. Bistua: Revista de la Facultad de Ciecias Básicas 13: 46-61

Cáffaro-Tommasiello EM, Latorre ME, Cepeda RE, Garitta L, Sosa M, Purslow PP (2018) Valoración de aspectos vinculados al consumo, calidad y seguridad de la carne, en consumidores argentinos de carne. Idesia (Arica) 36(3): 45-52

Carson CF, Mee BJ, Riley TV (2002) Mechanism of action of Melaleuca alternifolia (tea tree) oil on Staphylococcus aureus determined by time-kill, lysis, leakage, and salt tolerance assays and electron microscopy. Antimicrobial agents and chemotherapy 46(6): 1914-1920

Celikel N, Kavas G (2008) Antimicrobial properties of some essential oils against some pathogenic microorganisms. Czech Journal of Food Sciences-UZPI (Czech Republic)

Correa-Pacheco ZN, García-Paniagua KD, Bautista-Baños S, Corona-Rangel ML (2019) Efecto de nanorecubrimientos de quitosano-aceite esencial de tomillo sobre la calidad postcosecha en frutos de jitomate. Revista Mexicana de FitopatologÃa, Mexican Journal of Phytopathology 37(1)

Curioni A, Garcia M, Rolando A, Alfonso W, Arizio O (2002) Producción de orégano (Origanum vulgare L.) y tomillo (Thymus vulgaris L.) en el centro-oeste Bonaerense. Acta horticulturae

D’Auria M, Mauriello G, Marino R, Racioppia R (2005) Composition of volatile fractions from Thymus, Origanum, Lavandula and Acinos species. Journal of Essential Oil Bearing Plants 8(1): 36-51

de Bogota A. (2013). Resolución 2674 de 2013 Ministerio de Salud: Obtenido de http://www. alcaldiabogota. gov. co/sisjur/normas/Norma1. jsp.

Delgado H, Cedeño C, Montes de Oca N, Villoch A (2015) Calidad higiénica de la carne obtenida en mataderos de Manabí-Ecuador. Revista de Salud Animal 37(1): 1-9

Dorman H, Deans SG (2000) Antimicrobial agents from plants: antibacterial activity of plant volatile oils. Journal of applied microbiology 88(2): 308-316 
Dussault D, Vu KD, Lacroix M (2014) In vitro evaluation of antimicrobial activities of various commercial essential oils, oleoresin and pure compounds against food pathogens and application in ham. Meat Science 96(1): 514-520

Figueiredo AC, Barroso JG, Pedro LG, Scheffer JJ (2008) Factors affecting secondary metabolite production in plants: volatile components and essential oils. Flavour and Fragrance journal 23(4): 213226

Figueroa Delgado LY (2019) La calidad de la carne y la canal bovina en Colombia.

Gallegos-Flores PI, Bañuelos-Valenzuela R, Delgadillo-Ruiz L, Meza-López C, Echavarría-Cháirez F (2019) ACTIVIDAD ANTIBACTERIANA DE CINCO COMPUESTOS TERPENOIDES: CARVACROL, LIMONENO, LINALOOL, a-TERPINENO Y TIMOL. Tropical and Subtropical Agroecosystems 22: 241-248

Guerrero-Lagunes LA, Ruiz-Posadas LdM, Rodríguez-Mendoza MdIN, Soto-Hernández M, Castillo-Morales A (2011) Efecto del cultivo hidropónico de tomillo (Thymus vulgaris L.) en la calidad y rendimiento del aceite esencial. Revista Chapingo. Serie horticultura 17(2): 141-149

Huerta-Sanabria S, Arana-Coronado ÓA, Sagarnaga-Villegas LM, Matus-Gardea JA, Brambila-Paz JdJ (2018) Impacto del ingreso y carencias sociales sobre el consumo de carne en México. Revista mexicana de ciencias agrícolas 9(6): 1245-1258

ISO I (1985) 7609: 1985 Essential oils-Analysis by Gas Chromatography on Capillary Columns-General Method. International Organization for Standardization

Juliano C, Mattana A, Usai M (2000) Composition and in vitro antimicrobial activity of the essential oil of Thymus herba-barona Loisel growing wild in Sardinia. Journal of Essential Oil Research 12(4): 516-522

Juven B, Kanner J, Schved F, Weisslowicz H (1994) Factors that interact with the antibacterial action of thyme essential oil and its active constituents. Journal of applied bacteriology 76(6): 626-631

Kokkini S, Karousou R, Dardioti A, Krigas N, Lanaras T (1997) Autumn essential oils of Greek oregano. Phytochemistry 44(5): 883-886

Lambert R, Skandamis PN, Coote PJ, Nychas GJ (2001) A study of the minimum inhibitory concentration and mode of action of oregano essential oil, thymol and carvacrol. Journal of applied microbiology 91(3): 453-462

Lens-Lisbonne C, Cremieux A, Maillard C, Balansard G (1987) Methodes d'evaluation de l'activite antibacterienne des huiles essentielles: application aux essences de thym et de cannelle. J Pharm Belg 42(5): 297-302

López-Oviedo E, Aller A, Martin C, Castro C, Ramirez M, Pemán J, Cantón E, Almeida C, Martín-Mazuelos E (2006) Evaluation of disk diffusion method for determining posaconazole susceptibility of filamentous 
fungi: comparison with CLSI broth microdilution method. Antimicrobial agents and chemotherapy 50(3): 1108-1111

Muñoz López de Bustamante F. (2002). Plantas medicinales y aromáticas: Estudio, cultivo y procesado: Mundi-prensa.

Naghdi Badi H, Yazdani D, Ali SM, Nazari F (2004) Effects of spacing and harvesting time on herbage yield and quality/quantity of oil in thyme, Thymus vulgaris L. Industrial crops and products

No DCS (2008) 113 Política nacional de seguridad alimentaria y nutricional. Consejo Nacional de Política económica y social. República de Colombia. Departamento Nacional de planeación. Bogotá

Omidbaigi R, Arjmandi A (2001) Effects of NP supply on growth, development, yield and active substances of garden thyme (Thymus vulgaris L.)(Ed) 263-265.

Radulovic N, Blagojevic P, Stojanovic-Radic Z, Stojanovic N (2013) Antimicrobial plant metabolites: structural diversity and mechanism of action. Current medicinal chemistry 20(7): 932-952

Ramirez LS, Castaño DM (2009) Metodologías para evaluar in vitro la actividad antibacteriana de compuestos de origen vegetal. Scientia et technica 15(42): 263-268

Ray B, Bhunia A, Sánchez Monsiváis RI, Pineda Sánchez DG (2010) Fundamentos de microbiología de los alimentos.

Rodríguez EC, Díaz-Guevara P, Moreno J, Bautista A, Montaño L, Realpe ME, della Gaspera A, Wiesner M (2017) Vigilancia por laboratorio de Salmonella enterica en casos clínicos humanos en Colombia 2005 a 2011. Enfermedades Infecciosas y Microbiología Clínica 35(7): 417-425

Rota MC, Herrera A, Martínez RM, Sotomayor JA, Jordán MJ (2008) Antimicrobial activity and chemical composition of Thymus vulgaris, Thymus zygis and Thymus hyemalis essential oils. Food control 19(7): 681-687

Rueda-Puente EO, Juvera Bracamontes JJ, Romo López IG, Holguín Peña RJ (2018) Evaluación de la actividad antibacteriana in vitro de aceites esenciales de orégano y tomillo contra Ralstonia solanacearum. Revista mexicana de ciencias agrícolas 9(SPE20): 4251-4261

Skandamis P, Koutsoumanis K, Nychas G, Fasseas K (2001) Inhibition of oregano essential oil and EDTA on Escherichia coli 0157: H7 [food hygiene]. Italian Journal of Food Science (Italy)

Stoicov C, Saffari R, Houghton J (2009) Green tea inhibits Helicobacter growth in vivo and in vitro. International journal of antimicrobial agents 33(5): 473-478

Tajkarimi M, Ibrahim SA, Cliver D (2010) Antimicrobial herb and spice compounds in food. Food control 21(9): 1199-1218 
Talero García MC. (2019). Utilización de aceites esenciales en combinación con ácido láctico para extender la vida útil de carnes bovinas. Universidad Nacional de La Plata.

Ultee A, Bennik M, Moezelaar R (2002) The phenolic hydroxyl group of carvacrol is essential for action against the food-borne pathogen Bacillus cereus. Appl. Environ. Microbiol. 68(4): 1561-1568

Ultee A, Kets EP, Alberda M, Hoekstra FA, Smid EJ (2000) Adaptation of the food-borne pathogen Bacillus cereus to carvacrol. Archives of microbiology 174(4): 233-238

\section{Figures}

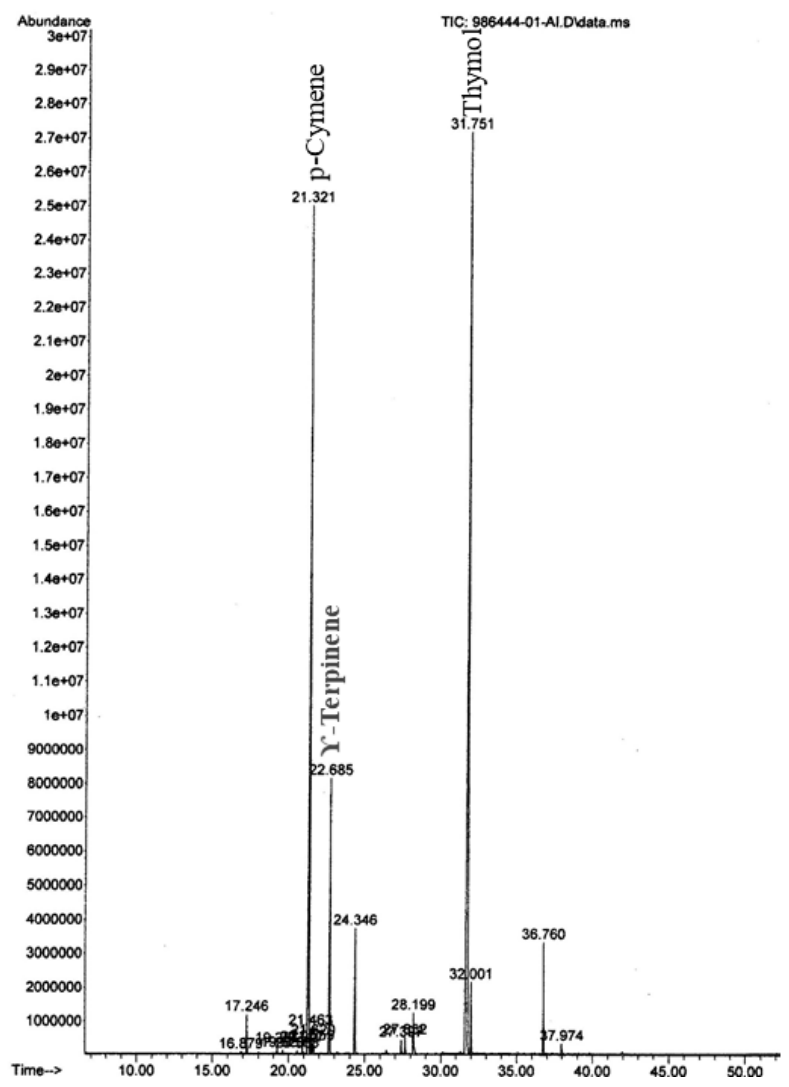

\section{Figure 1}

Chromatogram of the volatile compounds of the commercial essential oil of thyme. 
a)

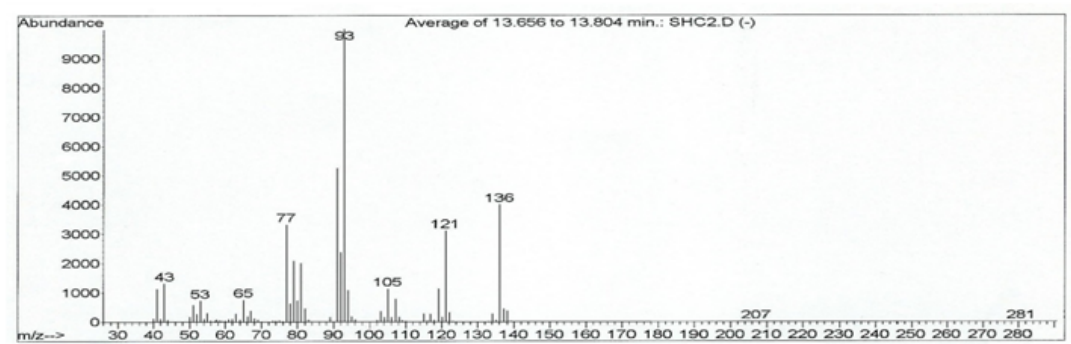

b)

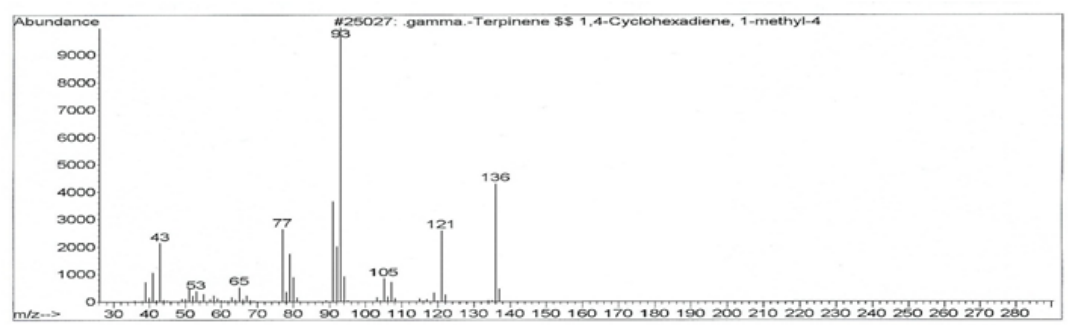

Figure 2

Mass spectrometry of Y-Terpinene compound (a) from the cEO sample and the Wiley 275.L database b).
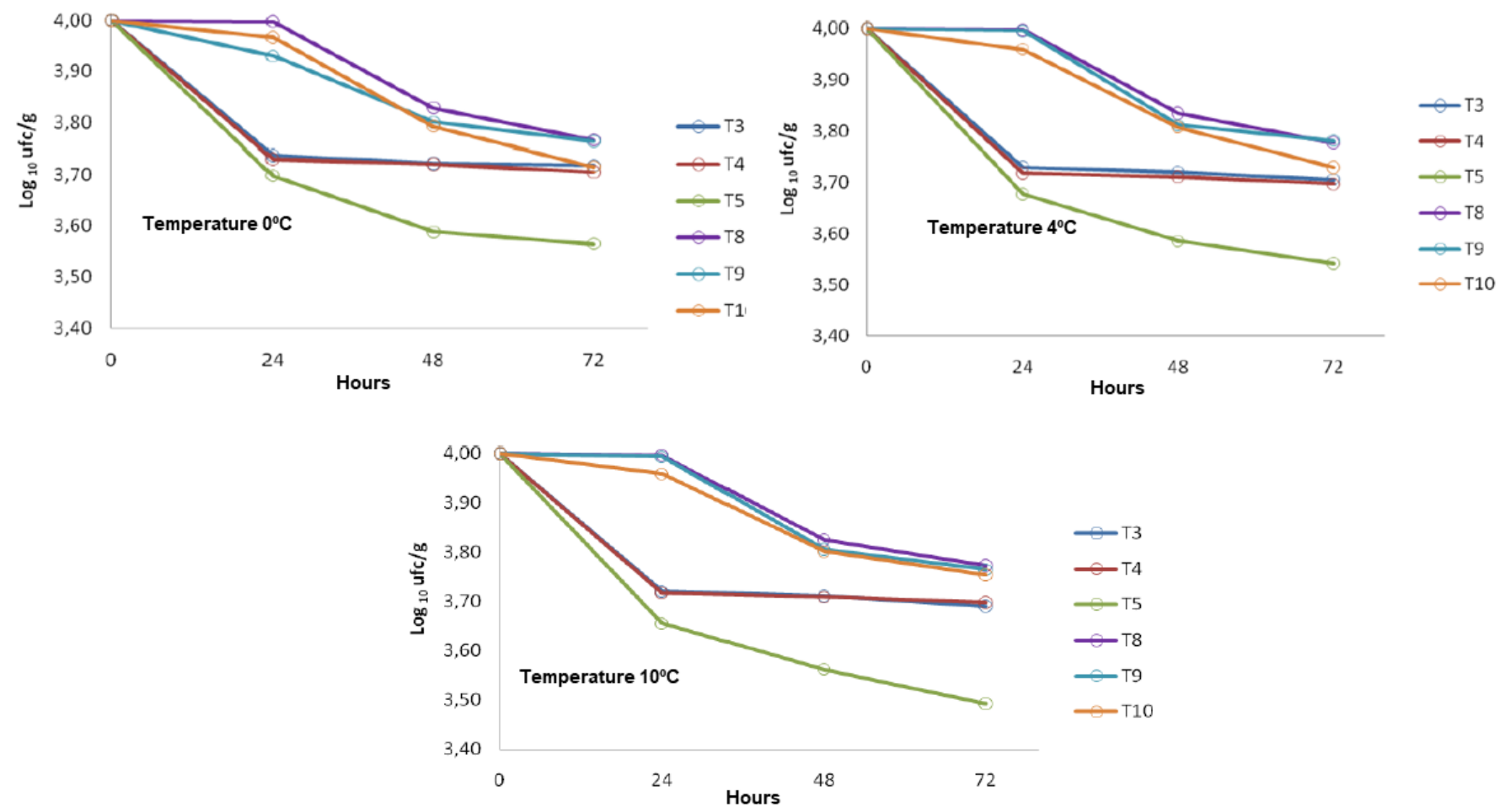
Figure 3

S paratyphi growth kinetics during 72 hours in chilled beef slices at different temperatures. Only the most effective treatments are shown.

\section{Supplementary Files}

This is a list of supplementary files associated with this preprint. Click to download.

- graphicalabstract.tif 